\title{
ISSN 2550-0023 \\ Pemilihan Metode Analisis Debit Banjir Rancangan Embung Coyo Kabupaten Grobogan
}

\author{
Anik Sarminingsih \\ Departemen Teknik Lingkungan, Fakultas Teknik, Universitas Diponegoro, Jl. Prof. Soedarto, \\ SH, Kampus Undip Tembalang, Semarang, Indonesia 50275 \\ E-mail: anikharieka@gmail.com
}

\begin{abstract}
Abstrak
Debit banjir rancangan merupakan salah satu parameter perencanaan bangunan air. Besaran debit banjir rancangan akan sangat berpengaruh pada dimensi serta tingkat stabilitas struktur bangunan.Rencana embung Coyo terletak di sungai Lampis,secara administrasi berada di antara desa Sidorejo dan desa Mlowokarangtalun kecamatan Pulokulon Kabupaten Grobogan. Untuk merencanakan dimensi bangunan pengelak digunakan Q25th, sementara untuk bangunan pelimpah digunakan Q100th. Tidak tersedianya data debit pengamatan pada lokasi kajian mengakibatkan analisis debit banjir dilakukan dengan model hujan-limpasan berdasarkan karakteristik DAS. Adanya fungsi tampungan maka diperlukan banjir rancangan dalam bentuk hidrograf. Beberapa metode analisis hidrograf yang sering digunakan di Indonesia di antaranya model Hidrograf satuan sintetik (HSS) Snyder dan HSS Nakayasu. Pemilihan besaran debit banjir dengan membandingkan hasil analisis dari berbagai metode tersebut dengan kapasitas penampang sungai (full bank capacity), dengan debit rencana kala ulang 2-5 tahun. Berdasarkan hujan rancangan dan karakteristik DAS Coyo dengan luas $69,56 \mathrm{~km}^{2}$, metode analisis debit banjir yang paling sesuai adalah HSS Nakayasu. Besarnya debit banjir rancangan $Q_{25 t h}=255,31 \mathrm{~m}^{3} /$ det, dan $Q_{100 t h}=327,70 \mathrm{~m}^{3} /$ det.
\end{abstract}

Kata kunci: banjir rancangan, kala ulang, hidrograf satuan sintetis

\begin{abstract}
Design of flood discharge is one of important parameter in planning of water structures. The magnitude of the design flood discharge will greatly affect the dimensions and the degree of stability of the structure. The Coyo dam plan is located in the Lampis river, administratively located between Sidorejo village and Mlowokarangtalun village, Pulokulon district, Grobogan district. To plan the dimension of diversion channel used Q25th, while for building spillway used Q100th. Unavailability of observational discharge data at the study site resulted in flood discharge analysis carried out with rainfall-runoff model based on watershed characteristics. The existence of the function of the flood hence required a design flood in the form of hydrograph. Several methods of hydrograph analysis are often used in Indonesia, among them are the synthetic unit Hydrograph (HSS) model of Snyder and HSS Nakayasu. Selection of flood discharge quantities by comparing the results of the analysis of the various methods with the full bank capacity, with the capacity of the discharge between the return period 2-5 years. Based on the rainfall design and characteristics of the Coyo basin with area of $69.56 \mathrm{~km}^{2}$, the most suitable flood discharge analysis method is HSS Nakayasu. The design flood discharge is $Q_{25 t h}=255,31 \mathrm{~m}^{3} / \mathrm{s}$, and $Q_{100 t h}=327,70 \mathrm{~m}^{3} / \mathrm{s}$.
\end{abstract}

Keywords: design flood, reordering, synthetic unit hydrograph

\section{PENDAHULUAN}

Analisa debit banjir digunakan untuk menentukan besarnya debit banjir rencana pada suatu DAS. Debit banjir rencana merupakan debit maksimum rencana di sungai atau saluran alamiah dengan periode ulang tertentu yang dapat dialirkan tanpa membahayakan lingkungan sekitar dan stabilitas sungai. Dalam perencanaan bangunan air, salah satu parameter disain yang sangat penting adalah besaran debit banjir kala ulang tertentu. Dalam perencanaan embung debit banjir digunakan sebagai dasar menentukan dimensi bangunan pengelak (diversion) saat pelaksanaan dan juga bangunan pelimpah (spillway). Dalam perencanaan bangunan pengelak digunakan debit banjir kala ulang 25 th, sementara untuk pelimpah digunakan debit banjir kala ulang 100th. Penentuan debit banjir rancangan idealnya dilakukan melalui data historis kejadian banjir, namun pada kasus tertentu sering digunakan melalui pendekatan hujan rancangan, sehingga sudah menjadi suatu keharusan bagaimana menentukan hujan rancangan jika data debit yang tersedia terbatas atau tidak ada. Seperti halnya DAS Coyo, dalam kajian ini tidak terdapat data pengamatan muka air (debit) sehingga analisis debit baniir digunakan model hujan- 
limpasan. Data yang diperlukan adalah data curah hujan serta karakteristik fisik DAS.Besaran curah hujan rancangan digunakan untuk memperkirakan besarnya debit banjir rencana baik secara rasional, empiris maupun statistik.

Rencana Embung Coyo, posisi as embung rencana terletak antara desa Mlowokarangtalun dan desa Sidorejo, kecamatan Pulokulon kabupaten Grobogan. Topografi lokasi embung cukup datar.Material dasar sungai berupa endapan alluvial.Tebing sungai rentan terhadap potensi longsoran.Penggunaan lahan mayoritas berupa daerah pertanian sawah tadah hujan, pertanian lahan kering, permukiman dan sebagian kecil berupa sawah irigasi teknis.

Tabel 1. Karakteritik morfometri DAS Coyo

\begin{tabular}{cccc}
\hline No & $\begin{array}{c}\text { Luas } \\
\left(\mathrm{km}^{2}\right)\end{array}$ & $\begin{array}{c}\text { Panjang } \\
\text { Sungai } \\
(\mathrm{m})\end{array}$ & $\begin{array}{c}\text { Slope } \\
\text { Maks. } \\
\text { Sungai } \\
(\mathrm{m} / \mathrm{m})\end{array}$ \\
\hline $\begin{array}{c}\text { Sub DAS } \\
\text { Coyo }\end{array}$ & 16,27 & 6685 & 0,0059 \\
$\begin{array}{c}\text { Sub DAS K. } \\
\text { Lampis }\end{array}$ & 53,22 & 15795 & 0,0041 \\
$\begin{array}{c}\text { Remaining } \\
\text { CA }\end{array}$ & 0,07 & 76 & 0,0045 \\
$\begin{array}{c}\text { Total DAS } \\
\text { Coyo }\end{array}$ & 69,56 & 22556 & 0,004833 \\
\hline
\end{tabular}

Luas DAS Embung Coyo sebesar 69,56 $\mathrm{km}^{2}$ yang terdiri dari dua sub DAS yakni Sub DAS Coyo dan Sub DAS Lampis. Kapasitas palung sungai di lokasi as embung sekitar 160 m3/dt.Untuk jelasnya karakteritik morfometri DAS di lokasi embung Coyo disajikan pada Tabel 1 dan Gambar 1.

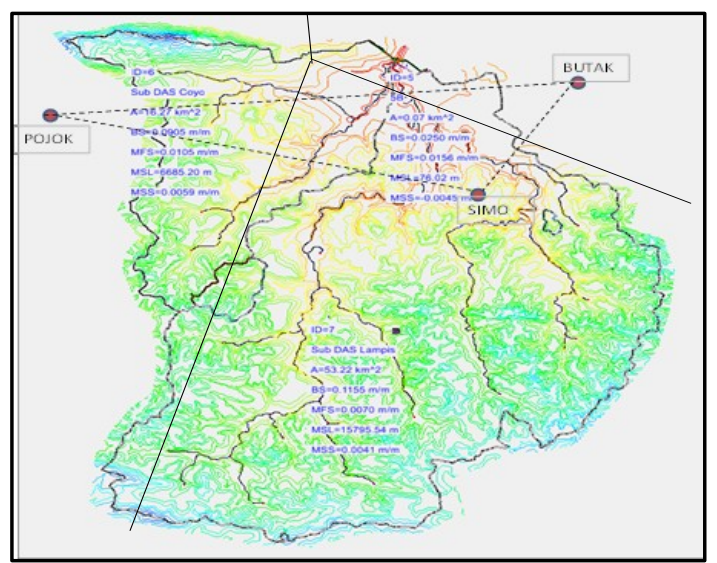

Gambar 1. Karakteristik DASdan Posisi pos hujan DAS Coyo

Data hujan tersedia dari 3 (tiga) pos hujan terdekat.Stasiun hujan yang diidentifikasi berpengaruh di DAS Embung Coyo yaitu Pos Hujan Butak, Pos Hujan Pojok dan Pos Hujan Simo.Data hujan tersebut diperoleh dari Dinas PSDA Propinsi
Jawa Tengah.Data hujan yang dikumpulkan adalah data hujan pada 10 tahun terakhir (2005-2014). Ketersediaan data hujan pada pos hujan tersebut cukup lengkap, berupa hujan harian Posisi koordinat pos hujan ditunjukkan pada Tabel 2.

Tabel 2. Posisi Pos Hujan DAS Coyo

\begin{tabular}{cccc}
\hline \multirow{2}{*}{ No } & \multirow{2}{*}{\begin{tabular}{c} 
Stasiun \\
\cline { 3 - 4 }
\end{tabular}} & \multicolumn{2}{c}{ Letakan Geografis } \\
\cline { 3 - 4 } & Guaris Lintang & Garis Bujur \\
\hline 1 & Butak & 513007,3677 & 9207041,5537 \\
2 & Pojok & 503477,6711 & 9207041,5537 \\
3 & Simo & 510706,0627 & 9203995,8435
\end{tabular}

- Sumber : Dinas PSDA Propinsi Jateng, 2016

Dalam analisis debit banjir data yang digunakan adalah data hujan harian maksimum. Hujan maksimum yang digunakan adalah hujan maksimum harian rata-rata dari ke tiga pos hujan yang tersedia. Hujan harian maksimum rata-rata DAS diperoleh dengan cara berikut (Suripin, 2004) :

- Tentukan hujan harian maksimum pada tahun tertentu di salah satu pos hujan

- Cari besarnya curah hujan pada tanggalbulan-tahun yang sama untuk pos hujan yang lain

- Hitung hujan DAS dengan salah satu cara menghitung hujan wilayah (rata-rata aljabar, polygon Thiesen atau Isohyet)

- Tentukan hujan maksimum harian (seperti langkah 1) pada tahun yang sama untuk pos hujan yang lain

- Ulangi langkah 2 dan 3 untuk setiap tahunnya.

Mengikuti tahapan seperti diuraikan tersebut, maka hujan harian maksimum dari ke tiga pos hujan telah dihitung.Perhitungan hujan wilayah digunakan metode Poligon Thiesen (Gambar 1).

Tabel 3. Hujan Wilayah DAS Coyo (mm)

\begin{tabular}{ccccc}
\hline $\begin{array}{c}\text { Tahun } \\
\text { Faktor } \\
\text { Thiesen }\end{array}$ & Pojok & Butak & Simo & $\begin{array}{c}\text { Hujan } \\
\text { Wilayah }\end{array}$ \\
\hline 2005 & 87 & 121 & 122 & 117.06 \\
2006 & 98 & 104 & 105 & 103.98 \\
2007 & 204 & 166 & 204 & 202.48 \\
2008 & 80 & 108 & 83 & 83.58 \\
2009 & 94 & 153 & 117 & 115.22 \\
2010 & 102 & 122 & 130 & 125.76 \\
2011 & 112 & 81 & 99 & 100.10 \\
2012 & 77 & 99 & 103 & 99.20 \\
2013 & 134 & 161 & 130 & 131.80 \\
2014 & 82 & 144 & 100 & 99.24 \\
\hline
\end{tabular}

Metode Poligon Thiessen dikenal juga sebagai metode rata-rata timbang (weighted mean). Cara ini memberikan proporsi luas 
ISSN 2550-0023

lahan daerah pengaruh pos penakar hujan untuk mengakomodasi ketidakseragaman jarak (Suripin, 2004).

Berdasarkan Poligon Thiessen tersebut di atas selanjutnya dapat dihitung luas wilayah masing-masing areal yang dipengaruhi oleh masing-masing stasiun hujan sebagaimana dan besarnya hujan wilayah DAS Coyo seperti ditunjukkan pada Tabel 3.

Pembangunan embung sebagai upaya memenuhi kebutuhan air masyarakat sangat diperlukan keberadaannya. Diperlukan perencanaan yang baik termasuk menentukan parameter perencanaan salah satunya berupa debitbanjir rencana yang sesuai dengan kondisi DAS serta hujan yang ada. Hal ini mengingat bangunan embung selain bermanfaat namun juga menyimpan potensi bahaya (dengan tampungan air yang besar). Pemilihan metode analisis menjadi penting karena hasil besaran banjir beberapa metode tidak akan sama. Metode yang dipilih yang memberikan hasil yang sesuai dengan kapasitas sungai di mana bangunan direncanakan.

\section{METODOLOGI PENELITIAN}

\section{Analisis Hujan Rencana}

Hujan rencana merupakan kemungkinan tinggi hujan yang terjadi dalam kala ulang tertentu sebagai hasil dari suatu rangkaian analisis hidrologi yang biasa disebut analisis frekuensi.Secara sistematis metode analisis frekuensi perhitungan hujan rencana ini dilakukan berurutan sebagai berikut.

- Parameter Statistik

- Pemilihan Jenis Metode

- Uji kebenaran Sebaran

- Perhitungan Hujan Rencana

\section{Parameter Statistik}

Pada kenyataannya bahwa tidak semua varian dari suatu variabel hidrologi terletak atau sama dengan nilai rata-ratanya. Variasi atau dispersi adalah besarnya derajat atau besaran varian di sekitar nilai rata-ratanya. Parameter yang digunakan dalam perhitungan analisis frekuensi meliputi parameter nilai rata-rata $(X)$. Standar deviasi $(\mathrm{Sd})$, koefisien variasi (Cv), koefisien kemiringan / skewness (Cs), dan koefisien kurtosis (Ck). Adapun caranya sebagai berikut

\section{a) Deviasi Standar (S)}

Jumlah aljabar dari penyimpangan harga variasi terhadap harga rata-rata selalu akan sama dengan nol, oleh karenanya tidak ada gunanya untuk mencarinya. Harga rata-rata dari penyimpangan, yang dinamakan keragaman (variance) adalah yang terbaik sebagai parameter dispersi. Besarnya keragaman sample dihitung dari keragaman populasi dengan memasukkan koreksi Bessel, yaitu (Soemarto, 1987) :

$$
\mathrm{Sd}=\sqrt{\frac{\sum(X i-X)^{2}}{n-1}}
$$

Dimana :

$\mathrm{Sd}=$ Standar Deviasi

$\bar{X} \quad=$ Tinggi hujan rata - rata selama $\mathrm{n}$ tahun $(\mathrm{mm})$

$\mathrm{Xi} \quad=$ Tinggi hujan di tahun $\mathrm{ke} \ldots(\mathrm{mm})$

$\mathrm{n} \quad=$ Jumlah tahun pencatatan data hujan

b) Koefisien Variasi

$$
C V=\frac{S d}{\bar{X}}
$$

dimana :

$\mathrm{CV}=$ koefisien varian

$\bar{X} \quad=$ nilai rata-rata varian

$\mathrm{Sd}=$ deviasi standar

c) Koefisien Skewness (CS)

Kemencengan (skewness) adalah suatu nilai yang menunjukkan derajat ketidaksimetrisan dari suatu bentuk distribusi

$$
C S=\frac{n \sum_{i=1}^{n}\left(X_{i}-\bar{X}\right)^{3}}{(n-1)(n-2) S d^{3}}
$$

dimana :

$\mathrm{CS}=$ koefisien skewness

$\mathrm{Xi} \quad=$ nilai varian $\mathrm{ke} \mathrm{i}$

$\bar{X}=$ nilai rata-rata varian

$\mathrm{n} \quad=$ jumlah data

$\mathrm{Sd}=$ deviasi standar

d) Koefisien Kurtosis

Pengukuran kurtosis dimaksud untuk mengukur keruncingan dari bentuk kurva distribusi, yang umumnya dibandingkan dengan distribusi normal.

$$
C K=\frac{n^{2} \sum_{i=1}^{n}\left(X_{i}-\bar{X}\right)^{4}}{S^{4}}
$$

dimana :

$\mathrm{CK}=$ koefisien kurtosis

$\mathrm{Xi} \quad=$ nilai varian $\mathrm{ke} \mathrm{i}$

$\bar{X}=$ nilai rata-rata varian

$\mathrm{n} \quad=$ jumlah data

$\mathrm{S}=$ deviasi standar

Pemilihan jenis sebaran bisa diindikasikan dengan membandingkan koefisien distribusi 
dari metode yang akan digunakan, seperti Tabel 4.

Tabel 4. Indikator Jenis Sebaran

\begin{tabular}{cc}
\hline Jenis Distribusi & Syarat \\
\hline Normal & $C s \approx 0$ \\
& $C k=3$ \\
Gumble & $C s \leq 1,1396$ \\
& $C k \leq 5,4002$ \\
Log Normal & $C s \approx 3 C v+C v^{2}=3$ \\
Log Pearson III & $C k=5,383$ \\
Cs $\neq 0$
\end{tabular}

Sumber: C.D. Soemarto

\section{Pengujian Distribusi}

Masing-masing distribusi memiliki sifatsifat khas sehingga setiap data hidrologi harus diuji kesesuaiannya dengan sifat statistik masing-masing distribusi tersebut.Ada dua jenis uji keselarasan ( Goodness of Fit Test ), yaitu uji keselarasan Chi Square dan Smirnov Kolmogorof. Pada tes ini biasanya yang diamati adalah nilai hasil perhitungan yang diharapkan.

Pengujian kecocokan sebaran dengan Smirnov-Kolmogorov dinilai lebih sederhana dibanding dengan pengujian dengan caraChiSquare. Dengan membandingkan kemungkinan (probability) untuk setiap varian, dari distribusi empiris dan teoritisnya, akan terdapat perbedaan $(\Delta)$ tertentu (Soewarno, 1995).

Apabila harga $\Delta_{\max }$ yang terbaca pada kertas probabilitas kurang dari $\Delta_{\text {kritis }}$ untuk suatu derajat nyata dan banyaknya varian tertentu, maka dapat disimpulkan bahwa penyimpangan yang terjadi disebabkan oleh kesalahan-kesalahan yang terjadi secara kebetulan (Soewarno, 1995).

\section{Distribusi Probabilitas}

1. Distribusi Normal

Perhitungan dengan distribusi normal secara praktis dapat didekati dengan persamaan sebagai berikut :

$$
\mathrm{X}_{\mathrm{T}}=\bar{X}+\text { z.S }
$$

dengan $: X_{T}=$ perkiraan nilai yang diharapkan terjadi dengan periode ulang T-tahun,

$\bar{X}=$ nilai rata-rata hitung variat,

$\mathrm{s}=$ deviasi standar nilai variat,

$z=$ faktor frekuensi dari distribusi normal (tabel $z$ untuk distribusi normal), merupakan fungsi dari peluang atau periode ulang dan tipe model matematik distribusi peluang yang digunakan untuk analisis peluang.

\section{Distribusi Log Normal}

Jika $Y=\log X$, maka perhitungan dengan distribusi normal secara praktis dapat didekati dengan persamaan sebagai berikut :

$\mathrm{Y}_{\mathrm{T}}=\bar{Y}+$ z.S

dengan $Y_{T}=$ perkiraan nilai yang diharapkan terjadi dengan periode ulang T-tahun,

$\bar{Y}=$ nilai rata-rata hitung variat, $\mathrm{s}=$ deviasi standar nilai variat,

$z=$ faktor frekuensi, merupakan fungsi dari peluang atau periode ulang dan tipe model matematik distribusi peluang yang digunakan untuk analisis peluang.

3. Distribusi Log-Pearson III

Jika $Y=\log X$, maka perhitungan dengan distribusi normal secara praktis dapat didekati dengan persamaan sebagai berikut :

$\mathrm{Y}_{\mathrm{T}}=\bar{Y}+\mathrm{K}_{\mathrm{T}} . \mathrm{S}$

dengan $Y_{T}=$ perkiraan nilai yang diharapkan terjadi dengan periode ulang T-tahun,

$\bar{Y}=$ nilai rata-rata hitung variat,

$\mathrm{s}=$ deviasi standar nilai variat,

$\mathrm{K}_{\mathrm{T}}=$ faktor frekuensi (tabel nilai $\mathrm{K}_{\mathrm{T}}$ untuk distribusi log pearson III), nilai $\mathrm{K}_{\mathrm{T}}$ ini tergantung dari koefisien kemencengan (skewness) dan probabilitasnya.

4. Distribusi Gumbel

Perhitungan curah hujan rencana menurut metode Gumbel, mempunyai perumusan sebagai berikut:

$\mathrm{X}_{\mathrm{T}}=\bar{X}+\mathrm{K} . \mathrm{s}$

dengan $X_{T}=$ perkiraan nilai yang diharapkan terjadi dengan periode ulang T-tahun,

$\bar{Y}=$ nilai rata-rata hitung variat,

$\mathrm{s}=$ deviasi standar nilai variat,

$\mathrm{K}=$ faktor frekuensi, merupakan fungsi dari peluang atau periode ulang dan tipe model matematik distribusi peluang yang digunakan untuk analisis peluang.

Faktor probabilitas $\mathrm{K}$ untuk harga-harga ekstrim Gumbel dapat dinyatakan dengan persamaan sebagai berikut :

$$
K=\frac{\mathrm{Y}_{\mathrm{T}}-\mathrm{Y}_{\mathrm{n}}}{\mathrm{S}_{\mathrm{n}}}
$$

Dengan $\mathrm{Yn}=$ reduced mean yang tergantung jumlah sampel/data $\mathrm{n}$, 
ISSN 2550-0023

$\mathrm{Sn}=$ reduced standard deviationyang juga tergantung pada jumlah sampel/data $\mathrm{n}$, $\mathrm{Y}_{\mathrm{Tr}}=$ reduced variate, yang dapat dihitung dengan persamaan sebagai berikut :

$Y_{T r}=-\mathrm{L}_{\mathrm{n}}\left\{-\mathrm{L}_{\mathrm{n}}\left[\frac{\mathrm{T}_{\mathrm{r}}-1}{\mathrm{~T}_{\mathrm{r}}}\right]\right\}$

Dengan $\mathrm{Tr}=$ kala ulang .

Pola Agihan Hujan

Pencatatan hujan biasanya dilakukan dalam satuan waktu harian, jam-jaman atau menit. Pencatatan biasanya dilakukan dengan interval waktu pendek supaya distribusi hujan selama terjadinya hujan dapat diketahui. Distribusi hujan yang terjadi digunakan sebagai masuk untuk mendapatkan hidrograf aliran.

Dalam studi ini untuk menentukan pola agihan hujan secara empiris digunakan cara Modified Mononobe, dikarenakan tidak tersedia data hujan durasi pendek (jamjaman). Rumus pola agihan hujan seperti berikut :

$$
R t=\frac{(T / t)^{2 / 3}}{T}
$$

\section{Dimana :}

$$
\begin{aligned}
& \mathrm{T}=\text { durasi hujan (jam), dalam kajian ini } \\
& \quad \text { digunakan } 6 \text { jam } \\
& \mathrm{t}=\text { lamanya hujan (jam) } \\
& \mathrm{R}_{\mathrm{t}}=\text { curah hujan maksimum harian }
\end{aligned}
$$$$
\text { (selama } 24 \text { jam) (mm) }
$$

\section{HSS Snyder}

Parameter yang dikembangkan dalam metode Hidrograf Satuan Sintetis Snyder terdiri dari empat parameter yaitu waktu kelambatan, aliran puncak, waktu dasar, dan durasi standar dari hujan efektif untuk hidrograf satuan dikaitkan dengan geometri fisik dari DAS dengan hubungan berikut.

$$
\begin{aligned}
& T_{p}=C_{t}\left(L L_{c}\right)^{0,3} \\
& Q_{p}=C_{P} A / t_{p} \\
& T=3+\left(t_{P} / 8\right) \\
& T_{D}=t_{P} / 5,5
\end{aligned}
$$

Apabila durasi hujan efektif trtidak sama dengan durasi standar $T_{D}$, maka:

$$
\begin{aligned}
& T_{p} R=t_{p}+0,25\left(t_{r}-t_{D}\right) \\
& Q_{p} R=Q_{p} t_{p} / t_{p} R
\end{aligned}
$$

$$
\begin{aligned}
& \text { dengan: } \\
& \text { tD } \quad \text { : durasi standar dari hujan efektif } \\
& \text { (jam) } \\
& \operatorname{tr} \quad: \text { durasi hujan efektif (jam) }
\end{aligned}
$$

tp : waktu dari titik berat durasi hujan efektif $T_{D}$ ke puncakhidrograf satuan (jam)

tpR : waktu dari titik berat durasi hujan tr ke puncak hidrograf satuan (jam)

$\mathrm{T}$ : waktu dasar hidrograf satuan (hari)

Qp : debit puncak untuk durasi tD

QpR: debit puncak untuk durasi tr

$\mathrm{L} \quad$ : panjang sungai utama terhadap titik kontrol yang ditinjau $(\mathrm{km})$

LC : jarak antara titik kontrol ke titik yang terdekat dengan titik berat DAS $(\mathrm{km})$

A : luas DAS $\left(\mathrm{km}^{2}\right)$

$\mathrm{Ct}$ : koefisien yang tergantung kemiringan DAS, yang bervariasi dari 1,4 sampai 1,7

$\mathrm{Cp}$ : koefisien yang tergantung pada karakteristik DAS, yang bervariasi antara 0,15 sampai 0,19

Dengan menggunakan rumus-rumus tersebut di atas dapat digambarkan hidrograf satuan. Untuk memudahkan penggambaran, berikut ini diberikan beberapa rumus:

$$
\begin{aligned}
& W_{50}=\frac{0,23 A^{1,08}}{Q_{p R}{ }^{1,08}} \\
& W_{75}=\frac{0,13 A^{1,08}}{Q_{p R}{ }^{1,08}}
\end{aligned}
$$

Dengan W50 danW75 adalah lebar unit hidrograf pada debit $50 \%$ dan $75 \%$ dari debit puncak, yang dinyatakan dalam jam. Sebagai acuan, lebar W50 dan W75 dibuat dengan perbandingan 1:2; dengan sisi pendek di sebelah kiri dari hidrograf satuan seperti pada Gambar 2 (Triatmodjo, 2006).

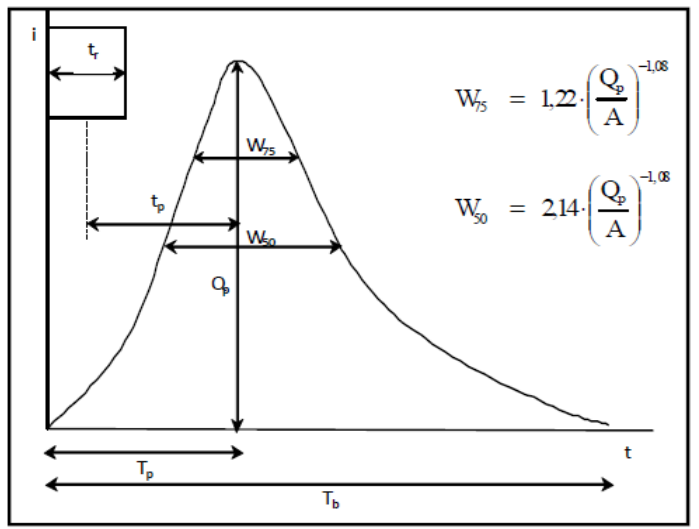

Gambar 2. Bentuk Umum HSS Snyder

2. Hidrograf Satuan Sintetis Nakayasu

Hidrograf satuan sintetis Nakayasu dikembangkan berdasarkan beberapa sungai di Jepang (Soemarto, 1987). Penggunaan metode ini memerlukan beberapa karakteristik parameter daerah alirannya, seperti :

a) Tenggang waktu dari permukaan hujan sampai puncak hidrograf (time of peak) 
b) Tenggang waktu dari titik berat hujan sampai titik berat hidrograf (time lag)

c) Tenggang waktu hidrograf (time base of hydrograph)

d) Luas daerah aliran sungai

e) Panjang alur sungai utama terpanjang (length of the longest channel)

Bentuk persamaan HSS Nakayasu adalah

$Q p=\frac{C A \cdot R o}{3,6\left(0,3 T p+T_{0,3}\right)}$

dengan :

$$
\begin{aligned}
& \mathrm{Qp}=\text { debit puncak banjir (m3/dt) } \\
& \mathrm{Ro}=\text { hujan satuan }(\mathrm{mm}) \\
& \mathrm{Tp}=\text { tenggang waktu dari permulaan } \\
& \text { hujan sampai puncak banjir(jam) } \\
& \text { T0,3= waktu yang diperlukan oleh } \\
& \text { penurunan debit, dari puncak sampai } \\
& 30 \% \text { dari debit puncak (jam) } \\
& \mathrm{CA}=\text { luas daerah pengaliran sampai } \\
& \text { outlet (km2) }
\end{aligned}
$$

Untuk menentukan $\mathrm{Tp}$ dan T0,3 digunakan pendekatan rumus sebagai berikut

$$
\begin{aligned}
& \mathrm{Tp}=\operatorname{tg}+0,8 \mathrm{tr} \\
& \mathrm{T} 0,3=\alpha \operatorname{tg} \\
& \mathrm{Tr}=0,5 \mathrm{tg} \text { sampai tg }
\end{aligned}
$$

tg adalah time lag yaitu waktu antara hujan sampai debit puncak banjir (jam). tg dihitung dengan ketentuan sebagai berikut :

- sungai dengan panjang alur $L>15 \mathrm{~km}$ : tg $=0,4+0,058 \mathrm{~L}$

- sungai dengan panjang alur $L<15 \mathrm{~km}$ : $\operatorname{tg}=0,21 \mathrm{LO}, 7$

Perhitungan T0,3 menggunakan ketentuan:

- $\alpha=2$ pada daerah pengaliran biasa

- $\alpha=1,5$ pada bagian naik hidrograf lambat, dan turun cepat

- $\alpha=3$ pada bagian naik hidrograf cepat, dan turun lambat

Pada waku naik : $0<\mathrm{t}<\mathrm{Tp}$

$$
\mathrm{Qa}=(\mathrm{t} / \mathrm{Tp})^{2,4}
$$

dimana Qa adalah limpasan sebelum mencapai debit puncak (m3/dt)

Pada kurva turun (decreasing limb) :

a) selang nilai : $0 \leq t \leq\left(T p+T_{0,3}\right)$

$$
\mathrm{Qd}_{1}=Q p .0,3^{\frac{\left(t-T_{p}\right)}{T_{0,3}}}
$$

b) selang nilai: $(T p+T 0,3) \leq t \leq(T p+T 0,3+$ $1,5 \mathrm{~T} 0,3)$

$$
\mathrm{Qd}_{2}=Q p \cdot 0,3^{\frac{\left(t-T p+0,5 T_{0,3}\right)}{1,5 T_{0,3}}}
$$

c) selang nilai : $t>(T p+T 0,3+1,5 \mathrm{~T} 0,3)$

$$
\mathrm{Qd}_{3}=\text { Qp.0,3 } 3^{\frac{\left(t-T p+1,5 T_{0,3}\right)}{2 T_{0,3}}}
$$

\section{HASIL DAN PEMBAHASAN}

Hujan Rancangan

Berdasarkan hujan wilayah seperti Tabel 3, serta menggunakan analisis statistik seperti diuraikan di atas, maka diperoleh parameter statistik seperti dirangkum pada Tabel 5.

Menggunakan parameter stastistik seperti ditunjukkan pada Tabel $\mathbf{5}$, selanjutnya bisa dihitung besarnya probabilitas hujan rancangan menggunakan berbagai distribusi frekuensi.Pemilihan distribusi yang sesuai dilakukan dengan uji kesesuaian distribusi menggunakan metode SmirnovKolmogorov.Hasilnya seperti ditunjukkan pada Tabel 6.

Dari hasil pengujian distribusi menggunakan metode Smirnov-Kolmogorov terlihat delta kritis $\left(\Delta_{\text {critic }}\right)$ tabel SmirnovKolmogorov untuk $n=11$ dan tingkat signifikansi $\alpha=5 \%$ sebesar 39.10 . Sementara

\begin{tabular}{|c|c|c|}
\hline Parameter & Data Asli & $\begin{array}{c}\text { Data } \\
\text { Logaritma }\end{array}$ \\
\hline Rata-2 & 115,58 & 4,72 \\
\hline Standev & 32,19 & 0,24 \\
\hline Variasi, z & 0,28 & 0,05 \\
\hline$z^{2}$ & 0,65 & \\
\hline Skew & 2,21 & 1,58 \\
\hline Kurtosis (Ck) & 5,84 & 3,45 \\
\hline Yn & 0,49960 & \\
\hline Sn & 0,96760 & \\
\hline
\end{tabular}
masing-masing distribusi teoritis dibandingkan dengan distribusi empiris (data) menunjukkan perbedaan maksimum $\left(\Delta_{\max }\right)$ sebesar $14.84 \%$, yang diperoleh pada distribusi Normal. Sehingga secara umum data hujan DAS Coyo bisa digunakan semua type distribusi. Namun jika dibandingkandengan parameter statistik untuk distribusi probabilitas maka distribusi yang sesuai adalah Log Normal, dengan nilai $\mathrm{Ck}=$ 5.83960. Sementara dengan nilai skewness Cs yang tidak sama dengan 0 , maka data tidak sesuai jika digunakan distribusi Normal.

Tabel 5. Parameter Statistik Hujan Wilayah DAS Coyo 
ISSN 2550-0023

Distribusi hujan

Mengacu pola agihan hujan menggunakan persamaan (11) dan hujan rancangan hasil analisis frekuensi metode distribusi Log Normal seperti Tabel 6, maka distibusi hujan selama 6 jam untuk berbagai kala ulang ditunjukkan pada Tabel 7. Data hujan jam-jaman ini selanjutnya sebagai input dalam analisis hidrograf satuan sintetis.

\section{Debit Banjir Rancangan Embung Coyo} Berdasarkan Model HSS Snyder

Parameter dan analisis HSS Snyder di DTA Embung Coyo :

\section{Luas Luas DAS A $=69,56 \mathrm{~km} 2$}

Panjang sungai Utama $L=15,795 \mathrm{~km}$ Jarak antara titik berat DAS ke outlet, Lc $=9,477 \mathrm{~km}$

Koefisian tergantung kemiringan DAS $\mathrm{Ct}=2,5$

Koefisien karakteristik DAS, Cp $=1,25$

Durasi hujan efektiftr $=2$,042Jam

Waktu dari titik berat durasi hujan efektif tp $=11,233 \mathrm{Jam}$

Debit Puncak Qp $=2,084 \quad \mathrm{~m} 3 / \mathrm{dt}$

Untuk menggambarkan hidrograf satuan digunakan persamaan Alexeyev

$$
\lambda=\left(\mathrm{Qp}{ }^{*} \mathrm{Tp}\right) /\left(\mathrm{h}^{*} \mathrm{~A}\right)=0.343 \text {, }
$$

dan $a=1.32^{\star} \lambda^{2}+0.15^{\star} \lambda+0.045=0.253$ sehingga hidrograf satuan bisa digambarkan seperti Gambar 3.

Menggunakan konsep konvolusi hidrograf maka bisa dihitung debit banjir untuk besaran hujan dari kala ulang 2 tahun hingga 100 th. Hasil analisis hidrograf banjir di DTA Embung Coyo menggunakan metode HSS Snyder ditunjukkan pada Gambar 4.

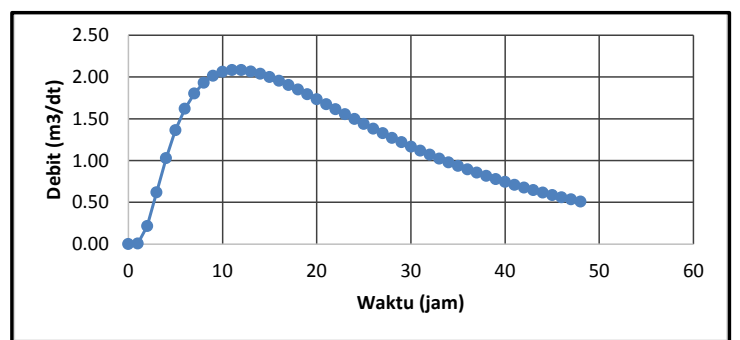

Gambar 3. HSS Snyder Embung Coyo

Berdasarkan karakteristik DAS dan distribusi hujan rancangan seperti Tabel $\mathbf{7}$, diperoleh parameter hidrograf satuan sintetis Snyder berupa waktu puncak banjir $\mathrm{Tp}$ $=11,472$ jam, debit puncak unit hidrograf $\mathrm{Qp}=$ $2,084 \mathrm{~m}^{3} / \mathrm{dt}$. Menggunakan hujan rencana berbagai kala ulang, dengan proses konvolusi hidrograf diperoleh debit banjir rencana kala ulang Q25 $=277,31 \quad \mathrm{~m}^{3} / \mathrm{dt}$ dan $\mathrm{Q} 100=345,37 \mathrm{~m}^{3} / \mathrm{dt}$.Besaran debit banjir rencana untuk kala ulang yang lain ditunjukkan pada Tabel 8.

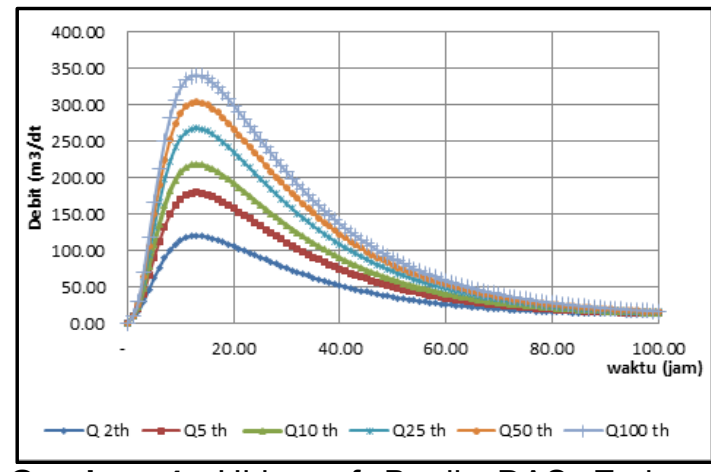

Gambar 4. Hidrograf Banjir DAS Embung Coyo dengan Metode Snyder

Debit Banjir Rancangan Embung Coyo Berdasarkan Model HSS Nakayasu

Hasil analisis parameter hidrograf satuan sintetis Nakayasu DAS Embung Coyo

Qp : Debit puncak banjir $=3,60 \mathrm{~m} 3 / \mathrm{s}$

A : luas DAS (km2) $\quad=69,56$

$\mathrm{Re}:$ curah hujan efektif $(\mathrm{mm})=1$

$\mathrm{Tp} \quad$ : Waktu dari permulaan banjir sampai puncak hidrograf banjir (jam) $=1,948$

$\mathrm{T}_{0.3}$ : Waktu dari puncak banjir sampai 0,3 kali debit puncak banjir (jam) $=2,63$

tg : Waktu konsentrasi (jam) $=1,36$

$\operatorname{Tr}$ :Satuan waktu curah hujan (jam) $=0,79$

a : koefisien karakteristik DAS $=2$

L : Panjang sungai utama $(\mathrm{Km})=15,8$

Menggunakan data seperti yang digunakan pada metode HSS Snyder, hasil analisis parameter hidrograf banjir menggunakan metode HSS Nakayasu, berupa waktu puncak banjir $\mathrm{Tp}=1,948$ jam, debit puncak unit hidrograf Nakayau $Q p=$ $3,60 \mathrm{~m} 3 / \mathrm{s}$ (Gambar 5). Juga dengan menggunakan distribusi hujan berbagai kala ulang dan proses konvolusi hidrograf diperoleh debit banjir rencana kala ulang Q25 $=255,31 \mathrm{~m}^{3} / \mathrm{dt}$ dan $\mathrm{Q} 100=327,70 \mathrm{~m}^{3} / \mathrm{dt}$, sementara debit banjir rencana untuk kala ulang yang lain seperti ditunjukkan pada Tabel 8 pada Gambar 6.

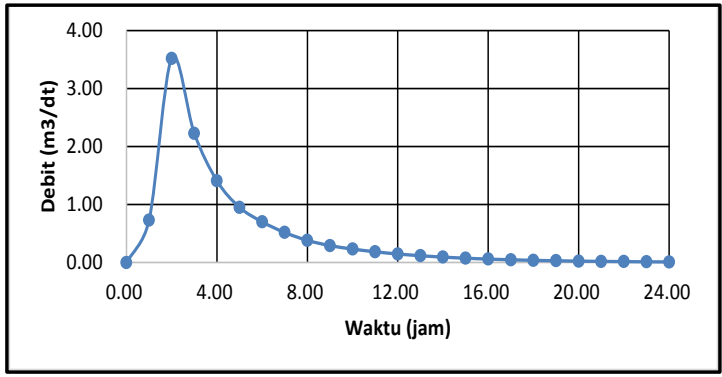

Gambar 5. HSS Nakayasu Embung Coyo 
Tabel 6. Hujan Rancangan Berbagai Distribusi Probabilitas di DAS Coyo

\begin{tabular}{ccccccc}
\hline \multirow{2}{*}{$\begin{array}{c}\text { Return } \\
\text { Period } \\
(\text { T Years) }\end{array}$} & $\mathrm{t}$ & Normal & $\begin{array}{c}\text { Log } \\
\text { Normal }\end{array}$ & $\begin{array}{c}\text { Gumbel } \\
\text { Extremal } \\
\text { Type I }\end{array}$ & $\begin{array}{c}\text { Pearson } \\
\text { Type III }\end{array}$ & $\begin{array}{c}\text { Log } \\
\text { Pearson } \\
\text { Type III }\end{array}$ \\
\cline { 3 - 7 } & & 115,58 & $\mathbf{1 0 7 , 6 1}$ & 111,16 & 105,41 & 106,05 \\
5 & 0,0000 & 142,68 & $\mathbf{1 3 4 , 5 5}$ & 148,87 & 133,78 & 131,76 \\
10 & 1,2816 & 156,84 & $\mathbf{1 5 4 , 9 7}$ & 173,83 & 156,13 & 153,49 \\
25 & 1,7507 & 171,94 & $\mathbf{1 8 3 , 4 6}$ & 205,38 & 186,74 & 186,80 \\
50 & 2,0537 & 181,70 & $\mathbf{2 0 6 , 5 4}$ & 228,78 & 210,64 & 216,36 \\
100 & 2,3263 & 190,48 & $\mathbf{2 3 1 , 1 4}$ & 252,01 & 235,14 & 250,50 \\
$\begin{array}{c}\text { Maximum Deviation } \\
\text { Critical Delta (Sig. }\end{array}$ & 14,84 & $\mathbf{1 0 , 2 1}$ & 14,45 & 13,40 & 12,30 \\
\multicolumn{2}{c}{ Level 5 \%) } & 39,10 & $\mathbf{3 9 , 1 0}$ & 39,10 & 39,10 & 39,10 \\
\hline
\end{tabular}

Tabel 7. Distribusi Hujan Rencana Embung Coyo

\begin{tabular}{cccccccc}
\hline \multirow{2}{*}{ Jam } & Distribusi & \multicolumn{7}{c}{ Hujan Rancangan dan Kala Ulang } \\
\cline { 2 - 8 } & $\%$ & $\mathrm{R}_{2} \mathrm{Th}$ & $\mathrm{R}_{5} \mathrm{Th}$ & $\mathrm{R}_{10} \mathrm{Th}$ & $\mathrm{R}_{25} \mathrm{Th}$ & $\mathrm{R}_{50} \mathrm{Th}$ & $\mathrm{R}_{100} \mathrm{Th}$ \\
\hline 1 & 55,03 & 59,22 & 74,05 & 85,28 & 100,96 & 113,66 & 127,20 \\
2 & 14,30 & 15,39 & 19,25 & 22,17 & 26,24 & 29,54 & 33,06 \\
3 & 10,03 & 10,80 & 13,50 & 15,55 & 18,41 & 20,72 & 23,19 \\
4 & 7,99 & 8,60 & 10,75 & 12,38 & 14,65 & 16,50 & 18,46 \\
5 & 6,75 & 7,26 & 9,08 & 10,45 & 12,38 & 13,93 & 15,59 \\
6 & 5,90 & 6,34 & 7,93 & 9,14 & 10,82 & 12,18 & 13,63 \\
Hujan Harian (mm/hari) & 107,61 & 134,55 & 154,97 & 183,46 & 206,54 & 231,14 \\
\hline
\end{tabular}

Hasil analisis debit banjir menggunakan metode hidrograf satuan sintetis (HSS) Snyder dan HSS Nakayasu menmberikan hasil yang relatif sama. Hal ini dikarenakan untuk mendapatkan besaran debit yang sesuai digunakan acuan kapasitas alur sungai (full bank capacity) yang pada umumnya besaranya setara dengan debit banjir kala ulang 2-5 tahunan. Untuk itu dalam penentuan parameter hidrograf difokuskan diperoleh debit puncak banjir kala ulang 2-5 tahun yang besarannya sekitar $160 \mathrm{~m}^{3} / \mathrm{dt}$.

Dengan demikian nilai debit banjir ke dua metode bisa hampir sama. Dilihat dari waktu puncak banjir (time to peak, Tp) dimana HSS Snyder $\mathrm{Tp}=11,233 \mathrm{jam}$ atau kecepatan air sekitar $0,39 \mathrm{~m} / \mathrm{dt}$, Sementara waktu puncak banjir dengan HSS Nakayasu Tp= 1,948 jam sehingga kecepatan aliran sekitar 2,25 m/det. Memperhatikan kecepatan aliran yang mungkin pada kondisi banjir, dimana terjadi pengikisan tebing sungai yang berupa material aluvial, maka kecepatan air dipastikan cukup besar. Dengan kecepatan aliran sekitar 0,39 m/dt maka tidak mampu menggerus, bahkan potensi terjadi endapan.
Sementara dengan kecepatan aliran lebih dari $2 \mathrm{~m} / \mathrm{dt}$, aliran cukup deras mampu mengerosi material dasar sungai hingga butiran kerikil, hal ini juga terlihat adanya longsoran tebing di beberapa ruas sungai. Untuk itu hidrograf banjir yang sesuai dengan karakteristik hujan dan morfometri DAS Coyo adalah hasil dari HSS Nakayasu.

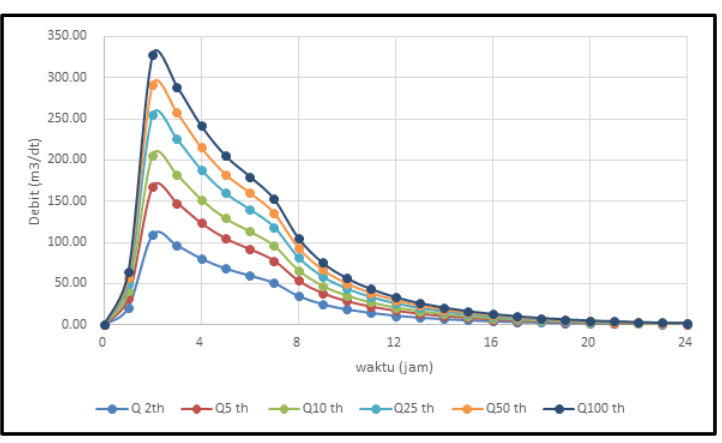

Gambar 6. Hidrograf Banjir DAS Embung Coyo dengan Metode Nakayasu

Besaran debit banjir rancangan dari kedua metode dirangkum pada Tabel 8 dan Gambar 7. 
Tabel 8. Perbandingan besaran debit Banjir berdasarkan metode HSS Snyder dan HSS Nakayasu (m3/det)

\begin{tabular}{ccc}
\hline $\begin{array}{c}\text { Kala } \\
\text { Ulang }\end{array}$ & $\begin{array}{c}\text { HSS } \\
\text { NAKAYASU }\end{array}$ & $\begin{array}{c}\text { HSS } \\
\text { SNYDER }\end{array}$ \\
\hline 2 & 109,05 & 167,00 \\
5 & 167,59 & 206,59 \\
10 & 206,35 & 236,26 \\
25 & 255,31 & 277,31 \\
50 & 291,64 & 310,34 \\
100 & 327,70 & 345,37 \\
\hline
\end{tabular}

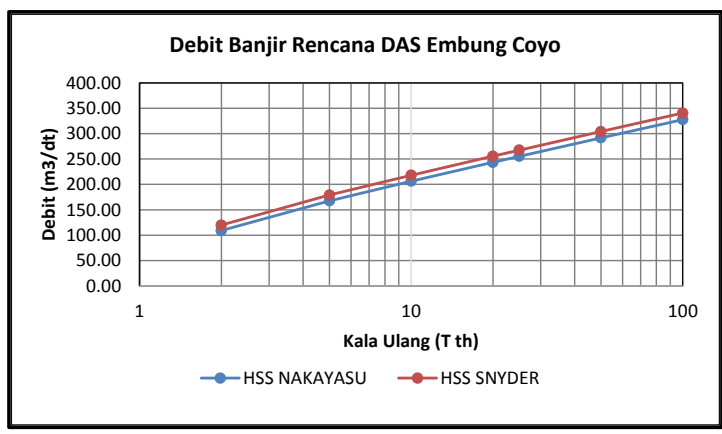

Gambar 7. Perbandingan Debit Banjir Rencana dengan HSS Snyder dan HSS Nakayasu

Dilihat dari waktu puncak banjir (time to peak, Tp) dimana HSS Snyder Tp $=11,233$ jam atau kecepatan air sekitar 0,39 m/dt, Sementara waktu puncak banjir dengan HSS Nakayasu $T p=1,948$ jam sehingga kecepatan aliran sekitar 2,25 m/det. Memperhatikan kecepatan aliran yang mungkin pada kondisi banjir, dimana terjadi pengikisan tebing sungai yang berupa material aluvial, maka kecepatan air dipastikan cukup besar. Dengan kecepatan aliran sekitar 0,39 m/dt maka tidak mampu menggerus, bahkan potensi terjadi endapan. Sementara dengan kecepatan aliran lebih dari $2 \mathrm{~m} / \mathrm{dt}$, aliran cukup deras mampu mengerosi material dasar sungai hingga butiran kerikil, hal ini juga terlihat adanya longsoran tebing di beberapa ruas sungai. Untuk itu hidrograf banjir yang sesuai dengan karakteristik hujan dan morfometri DAS Coyo adalah hasil dari HSS Nakayasu.

\section{KESIMPULAN}

Analisis banjir rencana di lokasi rencana embung Coyo menggunakan HSS Snyder dan HSS Nakayasu menghasilkan debit puncak yang hampir sama untuk berbagai kala ulang, dimana perbedaan debit banjir sekitar $10 \%$.Untuk itu meskipun besar debit puncak banjir dari ke dua metode hampir sama, namun hidrograf banjir yang dipilih adalah hasil dari metode HSS Nakayasu, dimana waktu puncak banjir yang lebih sesuai dengan karakteristik DAS Coyo. Pemilihan bentuk hidrograf ini akan sangat berpengaruh pada penelusuran (routing) tampungan embung dalam penentuan lebar pelimpah maupun saluran pengelak, dimana hasil routing berupa elevasi muka air rencana digunakan menentukan elevasi puncak embung maupun cofferdam.

\section{DAFTAR PUSTAKA}

Bambang Triatmodjo, 2008, Hidrologi Terapan, Beta offset, Yogyakarta.

Bedient, P, B, and W,C, Huber. 1992. Hydrology and Floodplan Analysis, Addison-WesleyPublishing Company, USA.

Chow, V,T,, Maidment, D,R, and Mays, L,W, .1988. Applied Hydrology, Mc Graw-Hill, Singapore.

I Made Kamiana. 2010. Teknik Perhitungan Debit Rencana Bangunan Air, Graha IImu, Yogyakarta.

Mutreja, K,N. 1986. Applied Hydrology, Tata Mc Graw-Hill, New Delhi,

Ponce, V, M, 1989, Engineering Hidrology Principles and Practice, Prentice Hall, New Jersey.

Soemarto, C,D, .1986. Hidrologi Teknik, Usaha Nasional, Surabaya.

Soewarno, .1995. Hidrologi - Aplikasi Metode Statistik untuk Analisa Data Jilid II, Nova, Bandung.

Suripin. 2004. Sistem Drainase Perkotaan Yang Berkelanjutan, ANDI, Yogyakarta. 